\title{
Recovery of sea urchin Diadema antillarum populations is correlated to increased coral and reduced macroalgal cover
}

\author{
Sarah Myhre, Alejandro Acevedo-Gutiérrez* \\ Department of Biology, Western Washington University, Bellingham, Washington 98225-9160, USA
}

\begin{abstract}
We surveyed the benthic community structure and population density of the longspined sea urchin Diadema antillarum on the shallow fore-reefs of the Gandoca-Manzanillo Wildlife Refuge, Caribbean Costa Rica, in September and October 2004. In zones with high densities of $D$. antillarum $\left(>0.6\right.$ ind. $\left.\mathrm{m}^{-2}\right)$, the cover of non-calcareous macroalgae, known coral competitors, was low and that of live coral was high, whereas the opposite occurred in zones with low densities of $D$. antillarum $\left(<0.1\right.$ ind. $\left.\mathrm{m}^{-2}\right)$. D. antillarum density was not related to the coverage of calcareous macroalgae, which are not viewed as coral competitors. Mean density of $D$. antillarum was 0.2 ind. $\mathrm{m}^{-2}$ and the total area covered by live coral was $14 \%$. D. antillarum density and area covered by live coral were 2 and 7 times larger, respectively, than those reported 4 yr earlier for the study site. Within the same period, the proportion contributed by non-calcareous macroalgae to total algal cover declined from $\sim 79$ to $48 \%$. Results indicate that various families of scleractinian corals in the Caribbean coast of Costa Rica have increased in abundance, that non-calcareous macroalgae have declined, and that recovering $D$. antillarum densities are correlated with these observations.
\end{abstract}

KEY WORDS: Diadema antillarum - Scleractinian coral · Costa Rica - Coral reef recovery . Macroalgae

\section{INTRODUCTION}

Coral reefs are the most taxonomically diverse and structurally complex marine ecosystems, providing habitat for numerous organisms. Over the last 2 decades, reef ecosystems have shifted from being coral-dominated to macroalgae-dominated (Carpenter 1990, Gardner et al. 2003). The compounding events that led to this change in the Caribbean Sea included the die-off of the long-spined sea urchin Diadema antillarum (Hughes 1994), mechanical damage from hurricanes (Lugo et al. 2000), eutrophication (Lapointe 1997) and overfishing (Jackson et al. 2001). The mass mortality of $D$. antillarum in the Caribbean reef ecosystem is the most spatially extensive die-off of a marine organism ever reported (Knowlton 2004). The mortality, first documented in Panama in 1983, was caused by an unknown pathogen transported by surface currents
(Lessios et al. 1983). Owing to the die-off of D. antillarum, herbivorous grazing pressure on fleshy, noncalcerous macroalgae was lifted and these organisms subsequently out-competed coral colonies for space, initiating the shift in the Caribbean reef ecosystem (Carpenter 1990, Gardner et al. 2003).

During the past few years, recovering populations of Diadema antillarum have been reported at several sites across the Caribbean (Edmunds \& Carpenter 2001, Miller et al. 2003, Carpenter \& Edmunds 2006). However, sites such as Panama and Florida have reported no measurable increases in populations of D. antillarum (Chiappone et al. 2002, Lessios 2005). Recent increases in $D$. antillarum density have been associated with significant reductions in non-calcareous macroalgal cover (Edmunds \& Carpenter 2001, Miller et al. 2003). One study also documented an 11fold increase in juvenile coral density in zones grazed 
by $D$. antillarum, providing the first indication that Caribbean reefs were returning from being dominated by macroalgae to again being coral-dominated ecosystems (Edmunds \& Carpenter 2001). Hence, observed coral reef recovery in the Caribbean, in particular the increase in coral recruitment and cover, may be mediated by the increased density of $D$. antillarum (Carpenter \& Edmunds 2006). If this is the case, rebounding D. antillarum populations in other Caribbean locations may also favor coral recovery.

In the present study, we surveyed the benthic community of Gandoca-Manzanillo Wildlife Refuge to determine if such recovery was occurring along the Caribbean coast of Costa Rica. We chose this location because previous estimates of the density of Diadema antillarum and cover of live coral in the area were available (Cortés 1992, Fonseca 2003), and because it has one of the largest fringing reefs of the Caribbean coast of Costa Rica. Our hypotheses were that D. antillarum density would be correlated to macroalgae abundance, and that coral cover would be correlated to D. antillarum density and macroalgae abundance.

\section{MATERIALS AND METHODS}

The Gandoca-Manzanillo Wildlife Refuge $\left(9^{\circ} 39^{\prime} \mathrm{N}\right.$, $82^{\circ} 42^{\prime} \mathrm{W}$ ) is located along an indentation of the southern Caribbean coast of Costa Rica. In 1992, an earthquake raised the coastline and adjacent reefs, uplifted fringing reefs, and created near-shore coral reefs that are accessible by foot (Cortés \& León 2002). We conducted the present study between September and October 2004 along a $1.2 \mathrm{~km}$ strip of beach that extends southward from the town of Manzanillo and that was also used in 2 previous studies (Cortés 1992, Fonseca 2003).

Transects were laid parallel to the shore in order to survey the study site. They were set at a maximum distance of $50 \mathrm{~m}$ from the shore in depths ranging from 1 to $7 \mathrm{~m}$. We randomly set 28 transects, each of which was $40 \mathrm{~m}$ long and $2 \mathrm{~m}$ wide. A $1 \times 1 \mathrm{~m}$ quadrat was randomly positioned along each transect in 10 locations to measure the percentage of the area covered by macroalgae, live coral, all other invertebrates and inorganic material (including dead coral). We were able to visually identify organisms in situ to species or genus. To quantify percent benthic cover within each quadrat, we counted the total number of $10 \times 10 \mathrm{~cm}$ squares that each organism covered. Once we finished estimating percent area covered by organisms in the quadrats, we counted the number of Diadema antillarum along the whole $40 \times 2 \mathrm{~m}$ transect and measured the test size of each individual.

Given that non-calcareous macroalgae compete with coral for space (Hughes 1989), we classified the total algal community at the study site into 2 groups: noncalcareous (or fleshy) macroalgae and calcareous macroalgae. For each transect, we calculated median $\%$ cover in order to estimate \% area covered by (1) calcareous macroalgae, (2) non-calcareous macroalgae and (3) live scleractinian coral. We also estimated the number of Diadema antillarum (ind. $\mathrm{m}^{-2}$ ) within each transect. We examined the hypothesis that $D$. antillarum density was associated with macroalgae abundance by relating $D$. antillarum density to area covered by calcareous and non-calcareous macroalgae, respectively, using correlation analyses. Because we conducted 2 simple regressions with the same independent variable, we set our significance level to 0.025 . We also examined the interaction among $D$. antillarum, macroalgae and coral by relating area covered by live scleractinian coral with that covered by calcareous and non-calcareous macroalgae and with $D$. antillarum density using multiple regression analysis. There was very little multi-colinearity in the multiple regression analysis because the independent variables were correlated. Although the multi-colinearity was not large enough to affect our results, we also performed an analysis to discard unnecessary independent variables, reduce the standard errors of $b$ (where $b$ is the regression coefficient) and obtain the best regression model based on high correlation coefficients and low square errors, specifically the square root of MSE and Mallow's Cp (Hintze 2001).

We transformed the variables to normalize data and achieve homoscedasticity before conducting the analyses. The dependent variable (Diadema antillarum density) was ln-transformed and the independent variables (area covered by calcareous and non-calcareous macroalgae) were arcsine transformed (Zar 1999).

\section{RESULTS}

The composition of the benthic community of Gandoca-Manzanillo Wildlife Refuge was (mean \pm SD) $14 \pm$ $8 \%$ live scleractinian coral, $29 \pm 11 \%$ non-calcareous macroalgae, $32 \pm 9 \%$ calcareous macroalgae, $3 \pm 3 \%$ other sessile invertebrates (such as sponges and anemones) and $>1 \pm 2 \%$ seagrass ( $n=28$ transects); the remaining substrate was composed of settled-out sediment particles, sand and dead coral. The 5 most common coral families comprised $14 \%$ of the total substrate (Table 1) and included the following species: Diploria strigosa, D. clivosa, D. labyrinthiformis, Favia fragum (Faviidae); Agaricia fragilis, A. agaricites, A. humilis, A. tenufolia, Helioceris cucullata (Agariciidae); Siderastrea siderea, S. radians (Siderastreidae); Millepora complanata (Milliporidae); Acropora palmata (Acroporidae). Of the total substrate covered by 
Table 1. Comparison of nearshore-reef community structure (density of Diadema antillarum, area cover of coral and macroalgae) within the GandocaManzanillo Wildlife Refuge, Costa Rica, in 1988, 2000 and 2004

\begin{tabular}{|c|c|c|c|}
\hline & $\begin{array}{c}1988 \\
(\text { mean) }\end{array}$ & $\begin{array}{l}\text { October } 2000 \\
(\text { mean } \pm \text { SD) }\end{array}$ & $\begin{array}{c}\text { October } 2004 \\
(\text { mean } \pm \text { SD) }\end{array}$ \\
\hline $\begin{array}{l}\text { D. antillarum density } \\
\text { (ind. } \mathrm{m}^{-2} \text { ) }\end{array}$ & Not measured & $0.10 \pm 0.22$ & $0.2 \pm 0.2$ \\
\hline Coral cover (\%) & 1.93 & $1.5 \pm 0.5$ & $14 \pm 8.0$ \\
\hline \multicolumn{4}{|l|}{ Selected coral families } \\
\hline Agariciidae & 0.16 & Not reported & $5 \pm 7.8$ \\
\hline Faviidae & 1.09 & Not reported & $4 \pm 5.4$ \\
\hline Siderastreidae & 0.30 & Not reported & $2 \pm 3.2$ \\
\hline Milliporidae & 0.01 & Not reported & $1 \pm 1.5$ \\
\hline Acroporiidae & 0.004 & Not reported & $>1 \pm 1$ \\
\hline Poritidae & 0.24 & Not reported & $>1 \pm>1$ \\
\hline Mussidae & 0.08 & Not reported & $>1 \pm>1$ \\
\hline \multicolumn{4}{|l|}{ Macroalgal cover (\%) } \\
\hline Calcareous macroalgae & Not measured & $\sim 21$ & 52 \\
\hline Non-calcareous macroalgae & Not measured & $\sim 79$ & 48 \\
\hline Source & Cortés (1992) & Fonseca (2003) & This study \\
\hline
\end{tabular}

macroalgae, non-calcareous species occupied slightly more than half, whereas calcareous species occupied slightly less (Table 1).

We observed 756 individual Diadema antillarum within the study site, most of which had a test size ranging from 41 to $70 \mathrm{~mm}$ (Fig. 1). Coral and macroalgae cover were related to the population density of D. antillarum, which averaged 0.2 ind. $\mathrm{m}^{-2}( \pm 0.2 \mathrm{SD})$. The area covered by non-calcareous macroalgae was negatively correlated to D. antillarum density (Fig. 2). In contrast, the area covered by calcareous macroalgae was not correlated to D. antillarum density (Pearson's correlation: $\mathrm{R}=0.042, \mathrm{p}=0.83$ ). According to multiple regression analysis, the area covered by live coral increased as D. antillarum density increased and diminished as noncalcareous macroalgae cover increased (Fig. 3, Table 2).

\section{DISCUSSION}

We observed an apparent recovery of Diadema antillarum and an increased abundance of several families of live coral in Gandoca-Manzanillo Wildlife Refuge. We observed a density of D. antillarum twice as high as that reported 4 yr earlier (Fonseca 2003); however, this sea urchin was still heterogeneously distributed within the study site, as indicated by the large SD obtained in both studies. We expect that $D$. antillarum abundance will continue to increase in the study area in near future given the large numbers of juveniles in the smallest 3 size classes (Fig. 1); a similar pattern of juvenile abundance was recorded at Jamaica and is indicative of larval recruitment processes (Edmunds \& Carpenter 2001). Our results support previous observations that $D$. antillarum appears to be recovering at both local and regional scales across the Caribbean Sea (Carpenter \& Edmunds 2006), and are significant because they were obtained from the southern Caribbean coast of Central America, a region not surveyed by Carpenter \& Edmunds (2006).

The recovery of Diadema antillarum appeared to be associated with an increased abundance of live coral within the refuge. In zones with high densities of $D$.

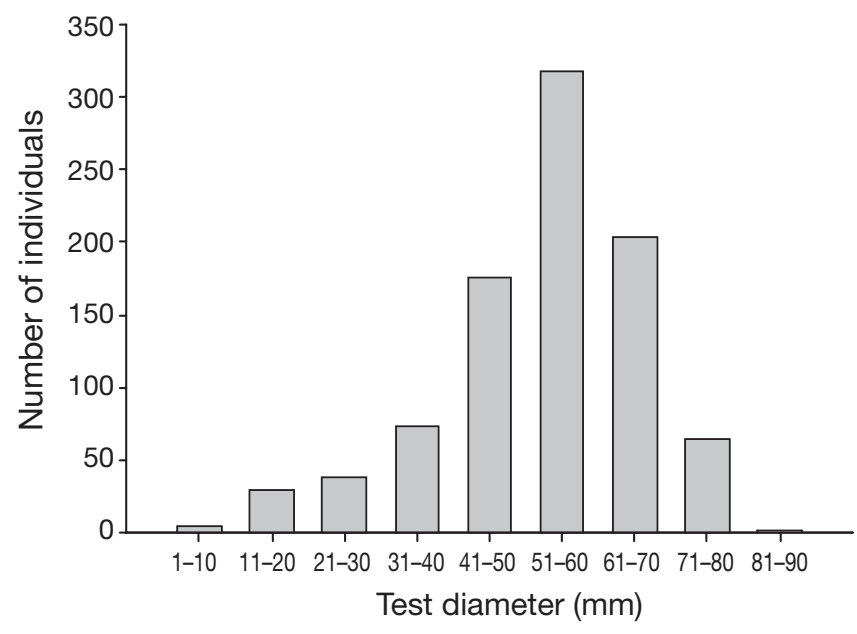

Fig. 1. Diadema antillarum. Size class frequency in nearshore coral reefs within the Gandoca-Manzanillo Wildlife Refuge, Costa Rica, September-October, 2004

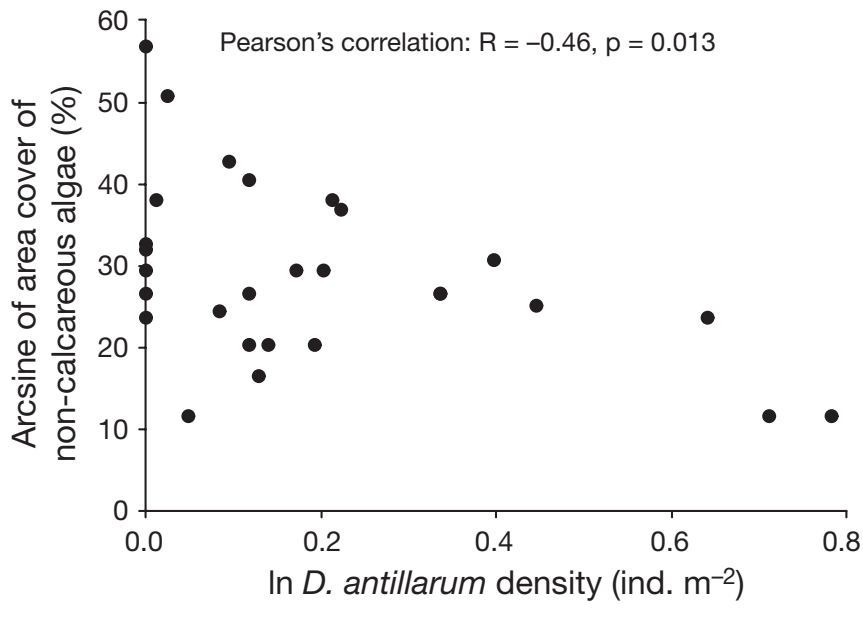

Fig. 2. Percent area cover of non-calcareous macroalgae relative to Diadema antillarum density in the GandocaManzanillo Wildlife Refuge, Costa Rica 


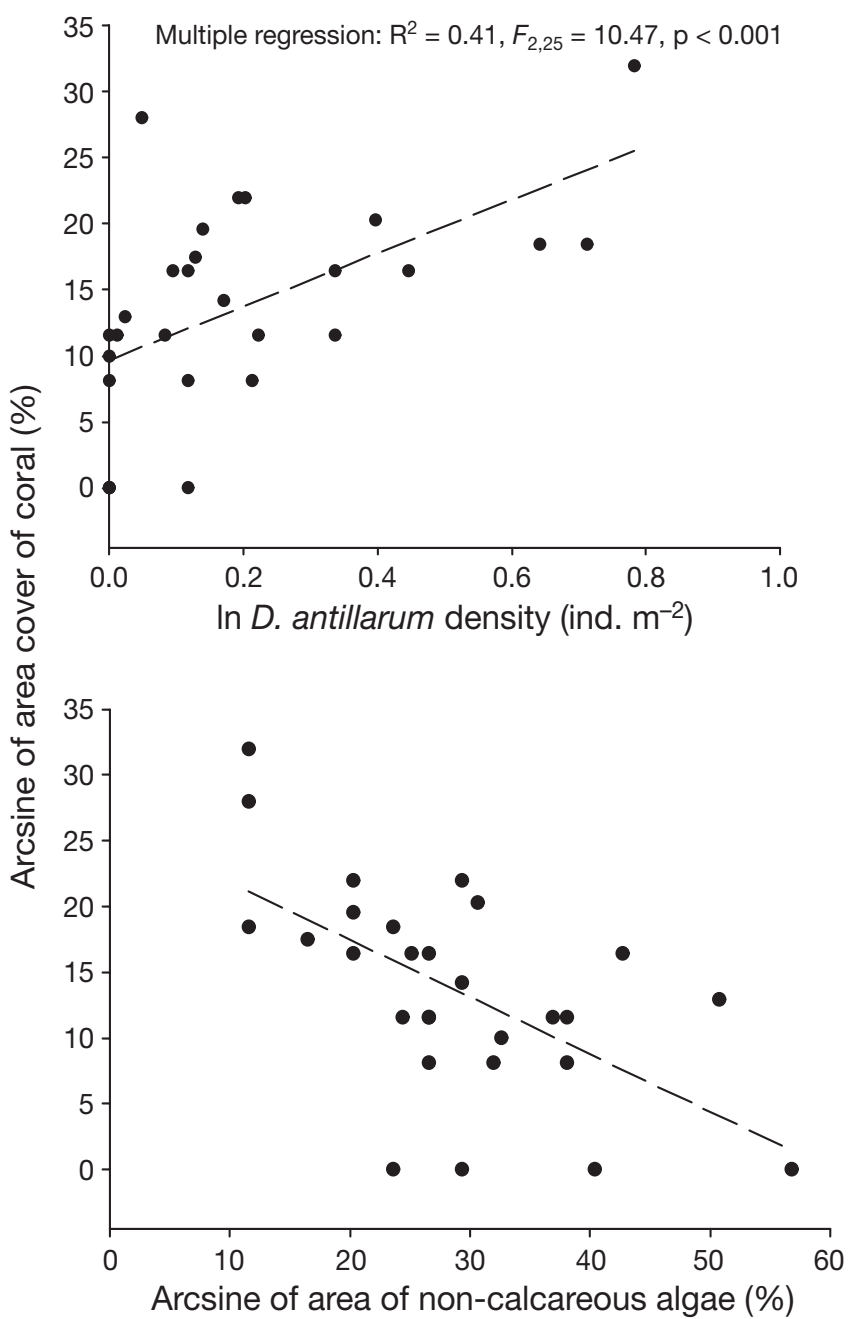

Fig. 3. Percent area cover of live coral relative to Diadema antillarum density and area cover of non-calcareous macroalgae in the Gandoca-Manzanillo Wildlife Refuge, Costa Rica antillarum, the cover of non-calcareous macroalgae was low, presumably as a result of herbivory (as suggested by sporadic observations of $D$. antillarum feeding on non-calcareous macroalgae). However, in zones with low densities of $D$. antillarum, we observed either low or high coverage of non-calcareous algae, suggesting that other factors may have been important in reducing algae coverage (Fig. 2). Results also suggested that the cover of non-calcareous macroalgae had an effect on the cover of live coral. In zones with high cover of non-calcareous macroalgae, the cover of coral was low, presumably as a result of competition for space (Fig. 3). Standardized regression coefficients indicated that coral cover was related to both non-calcareous macroalgae and D. antillarum density; however, the low $\mathrm{R}^{2}$ value suggested that other factors also affected coral cover (Table 2).

A relationship between Diadema antillarum density and composition of the benthic community can also be observed when comparing our results with those of 2 previous studies conducted in the refuge (Table 1). Concomitant with increases in D. antillarum density, live coral cover within the study site remained stable between 1988 and 2000; however, by 2004 it had increased from ca. 2 to $14 \%$ (Cortés 1992, Fonseca 2003; Table 1). Further, the relative area covered by calcareous macroalgae increased from over one-fifth of total algal cover in 2000 (Fonseca 2003) to one-half in 2004 (Table 1). Even when accounting for the slightly different methodologies used in the 3 studies, large differences in $D$. antillarum density, relative algal cover and live coral cover indicate that composition of the benthic community of the refuge has changed markedly since the initial study by Cortés (1992), supporting the hypothesis that live coral is recovering within the study site. One factor affecting this coral

Table 2. Area covered by scleractinian coral in relation to density of Diadema antillarum and coverage of 2 macroalgal functional groups (calcareous and non-calcareous). See definitions of macroalgae functional groups in 'Materials and methods'; $b$ : regression coefficient; $b^{\prime}$ : standardized regression coefficient; SR: square root; MSE: mean standard error

\begin{tabular}{|c|c|c|c|c|c|c|}
\hline Variable & $b$ & SE of $b$ & $t$ & $\mathrm{p}$ & $b^{\prime}$ & Overall regression \\
\hline \multicolumn{7}{|l|}{ Multiple linear regression } \\
\hline Constant & 16.977 & 6.785 & 2.502 & 0.020 & 0 & \multirow{4}{*}{$\begin{array}{l}\text { Adjusted } \mathrm{R}^{2}=0.40 \\
F_{3,24}=6.91 \\
\mathrm{p}=0.001 \\
\mathrm{SR} \text { of } \mathrm{MSE}=6.203\end{array}$} \\
\hline Ln $D$. antillarum density & 13.207 & 6.112 & 2.161 & 0.041 & 0.365 & \\
\hline $\begin{array}{l}\text { Arcsine of area of non-calcareous } \\
\text { macroalgal cover }\end{array}$ & -0.298 & 0.126 & -2.371 & 0.026 & -0.408 & \\
\hline $\begin{array}{l}\text { Arcsine of area of calcareous } \\
\text { macroalgal cover }\end{array}$ & 0.008 & 0.140 & 0.594 & 0.558 & 0.091 & \\
\hline \multicolumn{7}{|l|}{ Best regression model (see Fig. 3) } \\
\hline Constant & 20.051 & 4.326 & 4.635 & $<0.001$ & 0 & \multirow{3}{*}{$\begin{array}{l}\text { Adjusted } \mathrm{R}^{2}=0.41 \\
F_{2,25}=10.46 \\
\mathrm{p}<0.001 \\
\mathrm{SR} \text { of } \mathrm{MSE}=6.122\end{array}$} \\
\hline Ln $D$. antillarum density & 13.007 & 6.023 & 2.159 & 0.041 & 0.360 & \\
\hline Arcsine of area of non-calcareous & -0.313 & 0.122 & -2.572 & 0.016 & -0.428 & \\
\hline
\end{tabular}


recovery appears to be the reduction of benthic competition with non-calcareous macroalgae owing to increased densities of $D$. antillarum. Although our interpretation is based on correlative evidence, studies from other regions lend support to our conclusion (Hughes 1989, Edmunds \& Carpenter 2001, Miller et al. 2003, Carpenter \& Edmunds 2006).

The majority of coral families observed in the refuge appear to be increasing in cover (Table 1). With the exception of Poritidae, a weedy family that was perhaps replaced by other long-lasting species, representatives of most families recorded in 1988 (Cortés 1992) had increased in cover by 2004 . We believe this finding to be relevant because ecologically significant coral such as Montrastaea and Acropora still appear to be rare in other areas of the Caribbean with high Diadema antillarum density (Carpenter \& Edmunds 2006). Historically, the genus Acropora has been the primary builder of reef framework in shallow fore-reef zones across the Caribbean (Goreau \& Wells 1967, Goreau \& Goreau 1973). However, white-banded disease has been a significant source of mortality for the genus in Caribbean reefs (Aronson \& Precht 2001, Patterson et al. 2002). Hence, it is important that the species Acropora palmata has increased its coverage within our study site (Table 1). Nevertheless, the genus is still uncommon: colonies were often small, isolated and surrounded by macroalgae.

Because we conducted surveys in daylight, our methodology relied on the assumption that the diurnal location of Diadema antillarum is a good indicator of the area they graze. This assumption is supported by studies that revealed the foraging range of $D$. antillarum to be 0.5 to $1 \mathrm{~m}^{2}$; therefore, the area directly surrounding the daytime location of an urchin is likely to represent that individual's foraging area (Carpenter 1986).

It is not known if other factors also played a role in the recent recovery of coral reefs in the GandocaManzanillo Wildlife Refuge. In 1988, siltation owing to deforestation and agricultural practices and coral extraction were viewed as the 2 major threats to coral in the refuge (Cortés 1992). However, since that time, no further studies on the rate of sediment input into the system or harvest of corals have been conducted. It is possible that the increase in coral cover is actually a recovery from disturbance and uplift caused by an earthquake in 1992 (Cortés \& León 1992); however, if that were the case, one would expect to notice coral recovery relatively soon after the earthquake. Our results suggest that recovery of coral began no earlier than 2000. It is also possible that changes in the cover of coral and macroalgae are related to variable water clarity and inorganic nutrient concentrations at the refuge, which are known to affect their growth
(Muller-Parker \& Cortés 2001). Although little is known about abiotic factors at our study site, any such changes in water clarity and concentrations of available nutrients would have had to favor coral and calcareous macroalgae and not non-calcareous macroalgae.

Coral reef recovery is difficult to quantify because of the feasible temporal and spatial scales of ecological observation (Pandolfi 2002). Indeed, the possibility and nature of such recovery is currently debated (Rogers \& Miller 2006). However, our results indicate that increased densities of Diadema antillarum may favor the recovery of live coral and alter the composition of the benthic community of coral reefs within a relatively short time. Long-term monitoring of the abundance of D. antillarum, coral and macroalgae within GandocaManzanillo Wildlife Refuge, in addition to experimental manipulative field studies that evaluate cause and effect and the potential role of other factors in the recovery of live coral, are required to further elucidate this.

Acknowledgements. We thank the government of Costa Rica and community of Manzanillo for the provision of facilities. Funding was granted to S.M. from the PADI Foundation Grant and the Department of Biology at Western Washington University. We also thank R. Falletta for his assistance in the field. Comments by B. Bingham, J. Cortés, G. Muller-Parker, $\mathrm{J}$. Otto and anonymous reviewers improved this manuscript.

\section{LITERATURE CITED}

Aronson RB, Precht WF (2001) White-banded disease and the changing face of Caribbean coral reefs. Hydrobiologia 460:25-38

Carpenter RC (1986) Partitioning herbivory and its effects on coral reef algal communities. Ecol Monogr 54: $345-363$

Carpenter RC (1990) Mass mortality of Diadema antillarum. 1. Long-term effects on sea-urchin population-dynamics and coral-reef algal communities. Mar Biol 104:67-77

Carpenter RC, Edmunds PJ (2006) Local and regional scale recovery of Diadema promotes recruitment of scleractinian corals. Ecol Lett 9:271-280

Chiappone M, Swanson DW, Miller SL, Smith SG (2002) Large-scale surveys on the Florida Reef Tract indicate poor recovery of the long-spined sea urchin Diadema antillarum. Coral Reefs 21:155-159

Cortés J (1992) Los arrecifes coralinos del Refugio Nacional de Vida Silvestre Gandoca-Manzanillo, Limón, Costa Rica. Rev Biól Trop 40:325-333

Cortés J, León A (2002) Arrecifes coralinos del Caribe de Costa Rica. INBio, Santo Domingo de Heredia

Edmunds PJ, Carpenter RC (2001) Recovery of Diadema antillarum reduces macroalgal cover and increases abundance of juvenile corals on a Caribbean reef. Proc Natl Acad Sci USA 98:5067-5071

Fonseca EAC (2003) A rapid assessment at Cahuita National Park, Costa Rica, 1999 (Part 1: stony corals and macroalgae). Atoll Res Bull 496:248-257

Gardner TA, Cote IM, Gill JA, Grant A, Watkinson AR (2003) 
Long-term region-wide declines in Caribbean corals. Science 301:958-960

Goreau TF, Goreau NI (1973) The ecology of Jamaican coral reefs. II. Geomorphology, zonation and sedimentary phases. Bull Mar Sci 23:399-464

Goreau TF, Wells JW (1967) The shallow water Scleractinia of Jamaica: revised list of species and their vertical distribution range. Bull Mar Sci 17:442-453

Hintze J (2001) NCSS and PASS. Number cruncher statistical systems. NCSS Statistical Software, Kaysville, UT

Hughes TP (1989) Community structure and diversity of coral reefs: the role of history. Ecology 70:275-279

Hughes TP (1994) Catastrophes, phase-shifts, and large-scale degradation of a Caribbean coral reef. Science 265: 1547-1550

Jackson JBC, Kirby MX, Berger WH, Bjorndal KA and 15 others (2001) Historical overfishing and the recent collapse of coastal ecosystems. Science 293:629-638

Knowlton N (2004) Sea urchin recovery from mass mortality: new hope for Caribbean corals? Proc Natl Acad Sci USA 98:4822-4824

Lapointe BE (1997) Nutrient thresholds for bottom-up control of marcoalgal blooms on coral reefs in Jamaica and southeast Florida. Limnol Oceanogr 42:1119-1131

Lessios HA (2005) Diadema antillarum populations in Panama

Editorial responsibility: Otto Kinne (Editor-in-Chief), Oldendorf/Luhe, Germany twenty years following mass mortality. Coral Reefs 24: $125-127$

Lessios HA, Glynn PW, Robertson DR (1983) Mass mortality of coral reef organisms. Science 222:715

Lugo AE, Rogers CS, Nixon SW (2000) Hurricanes, coral reefs and rainforests: resistance, ruin and recovery in the Caribbean. Ambio 29:106-114

Miller RJ, Adams AJ, Ogden NB, Ogden JC, Ebersole JP (2003) Diadema antillarum 17 years after mass mortality: is recovery beginning on St. Croix? Coral Reefs 22:181-187

Muller-Parker G, Cortés J (2001) Spatial distribution of light and nutrients in some coral reefs of Costa Rica during January 1997. Rev Biol Trop 2:251-263

Pandolfi JM (2002) Coral communities at multiple scales. Coral Reefs 21:13-23

Patterson KL, Porter JW, Ritchie KB, Polson SW, Mueller E, Peters EC, Santavy DL, Smith GW (2002) The etiology of white pox, a lethal disease of the Caribbean elkhorn coral, Acropora palmata. Proc Natl Acad Sci USA 99:8725-8730

Rogers CS, Miller J (2006) Permanent 'phase shifts' or reversible declines in coral cover? Lack of recovery of two coral reefs in St. John, US Virgin Islands. Mar Ecol Prog Ser 306:103-114

Zar JH (1999) Biostatistical analysis, 4th edn. Prentice-Hall, Upper Saddle River, NJ

Submitted: February 28, 2006; Accepted: June 19, 2006 Proofs received from author(s): December 14, 2006 